\title{
Treatment of open fracture of shaft of tibia-fibula Gustilo type III-B by SIGN interlocking nail and wound coverage by muscle flap within 72 hours of injury
}

\author{
Ayub Ali ${ }^{1}$, Mizanur Rahman ${ }^{2}$, Sajedur Reza Faruquee ${ }^{3}$, Tazul Islam ${ }^{4}$, \\ Zamil Zaidur Rahim ${ }^{5}$, Abdullah Yusuf ${ }^{6}$
}

Department of Orthopaedics, ${ }^{1}$ Sadar General Hospital, Cox's Bazar, ${ }^{2}$ Gafargaon Upazilla Health Complex, Mymensingh, ${ }^{3}$ National Institute of Traumatology and Orthopaedic Rehabilitation, Dhaka, ${ }^{4}$ Upazilla Health Complex, Begumgonj, Noakhali, ${ }^{5}$ Combined Military Hospital, Comilla, Bangladesh

${ }^{6}$ Department of Microbiology, National Institute of Neurosciences \& Hospital, Dhaka, Bangladesh

Received: 03 June 2017

Revised: 19 July 2017

Accepted: 09 August 2017

\section{*Correspondence:}

Dr. Ayub Ali,

E-mail: drayubortho@gmail.com

Copyright: ( $)$ the author(s), publisher and licensee Medip Academy. This is an open-access article distributed under the terms of the Creative Commons Attribution Non-Commercial License, which permits unrestricted non-commercial use, distribution, and reproduction in any medium, provided the original work is properly cited.

\section{ABSTRACT}

Background: The open fracture of tibia-fibula Gustilo type III-B may threaten the survival of the injured leg. The objective of the study purpose was to see the effect of early coverage following fixation of open tibial shaft fracture.

Methods: This clinical trial was carried out in National Institute of Traumatology and Orthopaedic Rehabilitation (NITOR), Dhaka from July 2004 to June 2006 for a period of two (2) years. Patients at age group of 18 years or above with both sexes presented with open fracture shaft of tibia-fibula Gustilo type III-B were selected as study population. The patients were surgically managed by SIGN Interlocking nail and wound coverage by muscle flap within 72 hours of injury. Bacteriological study of the wound was done in all cases. All fixation and coverage were performed within 72 hours of injury. Patients grading improved on subsequent follow up. Evaluation of results was done at every postoperative follow up.

Results: A total number of 12 young patients with open fracture tibia-fibula Gustilo III-B were recruited for this study. Their age varies from 18 years to 48 years. A total number of $83.33 \%$ cases wound debridement was done within 12 hours of injury. Most of the soft tissue healed (91.67\%) within 0 to 20 days. There were no cases developed limb length discrepancy angulations or rotation. Superficial infections were occurred in $1(8.33 \%)$ case but no evidence of deep infection. In this study excellent result were obtained from 9 cases (75\%), good results were found in 2 cases $(16.67 \%)$, fair results from 1 case $(8.33 \%)$.

Conclusions: In conclusion early intramedullary fixation and exposed bone coverage by muscle flap is very important for prevention of infection, minimizing bone death simultaneously enhances bone healing.

Keywords: Open fracture, Gustilo type III-B, SIGN interlocking nail, Muscle flap

\section{INTRODUCTION}

Treatment of open fracture of tibia is difficult due to poor soft tissue coverage and blood supply of tibial shaft. Tibial fractures are also associated with high risk of infection, nonunion and malunion. Half a century ago
Charnley was hopeful to find out the best method of treating a fracture of the shaft of tibia which can be stated with finality. ${ }^{1}$ When the fracture is open, the condition is even more complex for contamination, and for highenergy injury, survivability of the limb and sometimes life is hanging in the balance. ${ }^{2,3}$ Therefore, the debate is 
to be or not to be the question of amputation or salvagelife or limb. ${ }^{3-5}$ There is universal agreement that open fractures require emergency treatment including adequate debridement and irrigation of the wound; then open fracture should be stabilized as soon as possible and is posted for early soft-tissue cover preferably within 72 hours. $^{6-8}$ Despite this the question of amputation or salvage for the more severe injuries still generates heated debate. $^{8-10}$ Primary collaboration by orthopaedic and plastic surgeons as a team has many potential advantages and has been widely recommended and has been emphasized. ${ }^{11-15}$ Unfortunately in practice, this facility is often unavailable.

Several works have been done in past at National Institute of Traumatology and Orthopaedic Rehabilitation (NITOR) on the treatment of open tibial fracture like fixation by external fixator, indigenous external fixator, unreamed inter locking SIGN nail, soft tissue coverage by gastrocnemius muscle flap, combined gastrocnemius and soleus muscle flap. ${ }^{16-21}$ None of the above series were able to cover the bone in 72 hours for delayed referral and inadequate debridement initially. In most orthopedic centre in Bangladesh these injuries are managed by wound debridement and application of plaster cast or external fixator with subsequent referral to a department of plastic surgery for delayed soft tissue reconstruction. Individually they usually have limited personal experience of the serious injuries. In this context the present study was undertaken to find out an acceptable method of treatment of open tibial shaft fracture Gustilo type III-B and to provide stability at the fracture site by interlocking nail.

\section{METHODS}

This clinical trial was carried out in National Institute of Traumatology and Orthopaedic Rehabilitation (NITOR), Dhaka from July 2004 to June 2006 for a period of two (2) years. Patients presented with open fracture of shaft of tibia-fibula Gustilo type III-B at age group of 18 years of above adults with both sexes were selected as study population. The patients were managed by SIGN Interlocking nail and wound coverage by muscle flap within 72 hours of injury. It was a purposive sampling method following preset inclusion and exclusion criteria. Patients with fracture shaft of tibia which was $8 \mathrm{~cm}$ below the knee and $6 \mathrm{~cm}$ above the ankle with the age group of 18 years and above, open fracture shaft of tibiafibula Gustilo type III-B within 72 hours were included as study population. Fracture in children, Gustilo type I, II, IIIA \& IIIC, fracture shaft of tibia and fibula $8 \mathrm{~cm}$ close to knee and $6 \mathrm{~cm}$ close to ankle as well as fracture already fixed by external fixation were excluded from this study. Informed written consents from all patients included in the study were taken before management. After initial resuscitation, wound debridement was done at emergency operation theater. After pre-anesthetic check-up, fracture fixation was done by SIGN nail and wound coverage by muscle flap under spinal anesthesia at same or different sittings. All above procedures were done within 72 hours of injury. Statistical analysis was performed by Statistical Package for Social Science (SPSS version 20.0, USA). The quantitative variables were expressed as frequency and percentage. The qualitative data were compared with Chi-square test to see the level of significance. $P$ value less than 0.05 was taken as statistically significance.

\section{RESULTS}

This clinical trial comprises 12 young patients with open fracture tibia- fibula Gustilo III-B. Their age varied from 18 years to 48 years with an average 34 years of which 11 were male and 1 was female. Out of 12 cases 8 cases were involved in right side and 4 cases were in left side. Out of 12 patients, 5 patients were manual labour, 2 patients were student 2 patients were service holder, 2 patients were farmer and 1 patient was housewife. 11 cases were victim of motor vehicle accident and only 1 case suffered from occupational injury. Bacteriological study of the wound was done in all cases and major infecting organism was Staphylococcus aureus (Table 1).

Table 1: Distribution of isolated bacteria from wound swab.

\begin{tabular}{|lll|}
\hline Bacteria & Frequency & Percentage \\
\hline No-growth & 4 & 33.34 \\
\hline Staphylococcus aureus & 5 & 41.67 \\
\hline Streptococcus pyogenes & 1 & 8.33 \\
\hline E. coli & 1 & 8.33 \\
\hline Kliebsiella species & 1 & 8.33 \\
\hline Total & 12 & 100.0 \\
\hline
\end{tabular}

Out of 12 cases wound coverage done in 4 cases by gastronemius muscle flap, 5 cases by soleus muscle flap and 3 cases by combined gastrocnemius and soleus muscle flap (Table 2).

Table 2: Distribution of muscle flap among the study population.

\begin{tabular}{|lll|}
\hline Name of muscle flap & Frequency & Percentage \\
\hline Gastrocnemius & 4 & 33.33 \\
\hline Soleus & 5 & 41.67 \\
\hline $\begin{array}{l}\text { Combined } \\
\text { gastrocnemius and } \\
\text { soleus }\end{array}$ & 3 & 25 \\
\hline Total & 12 & 100.0 \\
\hline
\end{tabular}

The study purpose was to see the effect of early coverage following fixation so early coverage demand a good early debridement. $83.33 \%$ cases wound debridements were done within 12 hours of injury (Table 3 ). 
After debridement all fracture were fixed by SIGN nailing. Out of 12 cases, site of fracture of 6 cases were at the middle third, 4 cases at the upper third and 2 cases at the lower third (Table 4).

Table 3: Time gap from injury to wound debridement.

\begin{tabular}{|l|l|l|}
\hline Time gap & Frequency & Percentage \\
\hline 0 to 6 hours & 6 & 50.0 \\
\hline 7 to 12 hours & 4 & 33.33 \\
\hline 12 to 24 hours & 2 & 16.67 \\
\hline Total & 12 & 100.0 \\
\hline
\end{tabular}

Table 4: Distributions of study population according to site of fracture.

\begin{tabular}{|lll|}
\hline Site of fracture & Frequency & Percentage \\
\hline Upper third & 4 & 33.33 \\
\hline Middle third & 6 & 50.00 \\
\hline Lower third & 2 & 16.67 \\
\hline Total & 12 & 100.0 \\
\hline
\end{tabular}

Most of fractures fixation was done within 49 to 72 hours of injury as well as the coverage (Table 5). All fixation and coverage was performed within 72 hours of injury. The gap from injury to SIGN nailing was shown in Table 6.

Table 5: Distribution of time of flap coverage.

\begin{tabular}{|lll|}
\hline Flap coverage time & Frequency & Percentage \\
\hline 0 to 24 hours & 0 & 0.0 \\
\hline 25 to 48 hours & 4 & 33.33 \\
\hline $\mathbf{4 9}$ to $\mathbf{7 2}$ hours & 8 & 66.67 \\
\hline Total & 12 & 100.0 \\
\hline
\end{tabular}

Table 6: Time gap from injury to SIGN nailing.

\begin{tabular}{|lll|}
\hline Hours after trauma & Frequency & Percentage \\
\hline 0 to 24 Hours & 0 & 0.0 \\
\hline 25 to 48 Hours & 5 & 41.67 \\
\hline 49 to 72 Hours & 7 & 58.33 \\
\hline Total & 12 & 100.0 \\
\hline
\end{tabular}

Most of the soft tissue healed (91.67\%) within 0-20 days. In this series superficial infection were occurred in 1 case $(8.33 \%)$ but no evidence of deep infection (Table 7$)$.

Table 7: Duration of soft tissue healing.

\begin{tabular}{|lll|}
\hline Soft tissue healing & Frequency & Percentage \\
\hline 0 to 10 days & 2 & 16.67 \\
\hline $\mathbf{1 0}$ to 20 days & 9 & 75.0 \\
\hline $\mathbf{2 0}$ to 30 days & 1 & 8.33 \\
\hline Total & 12 & 100.0 \\
\hline
\end{tabular}

Total time of hospital stay counted from the day of admission at NITOR up to the day of discharge of the patient, which reduced significantly, average hospital stay were 17.58 days (Table 8).

Table 8: Distribution of duration of hospital stay.

\begin{tabular}{|lll|}
\hline Hospital stay & Frequency & Percentage \\
\hline 11 to 15 days & 4 & 33.33 \\
\hline 16 to 20 days & 5 & 41.67 \\
\hline More than 21 days & 3 & 25.00 \\
\hline Total & 12 & 100.0 \\
\hline
\end{tabular}

Out of 12 cases, follow up duration of 6 cases were 7 to 10 weeks, 3 cases were less than 7 weeks, 2 cases were 11 to 14 weeks and 1 case was 16 weeks. Average follow-up duration was 9.25 months. There were no cases developed limb length discrepancy angulations or rotation. In this series out of 12 cases, only 2 case $(16.67 \%)$ developed restricted knee joint motion. In this series only $2(16.67 \%)$ cases, developed restricted ankle joint motion. There was no nonunion and out of 12 cases, fracture union of $9(75 \%)$ cases occurred within 24 weeks and $3(25.0 \%)$ cases within 40 weeks (Table 9 ).

Table 9: Distribution of fracture union time.

\begin{tabular}{|lll|}
\hline Time (weeks) & Frequency & Percentage \\
\hline $\mathbf{1 2}$ to $\mathbf{2 4}$ & 9 & 75.0 \\
\hline $\mathbf{2 5}$ to 40 & 3 & 25.0 \\
\hline More than 40 & 0 & 0.0 \\
\hline Total & 12 & 100.0 \\
\hline
\end{tabular}

\section{Final outcome}

In this study Tucker et al criteria was used for evaluation of the outcome. ${ }^{19}$ Excellent and good results were taken as acceptable and satisfactory results. Evaluation of results was done at every postoperative follow up. Patients grading improved on subsequent follow up. In this study excellent result were obtained from 9 cases (75\%), good results were found in 2 cases $(16.67 \%)$, fair results from 1 case $(8.33 \%)$. Therefore the satisfactory results were $91.67 \%$ (Table 10).

Table 10: Showing final outcome of the study.

\begin{tabular}{|cll|}
\hline Grading of the result & Frequency & Percentage \\
\hline Satisfactory $(\mathbf{n = 1 1})$ & & \\
\hline Excellent & 9 & 75.0 \\
\hline Good & 2 & 16.67 \\
\hline Unsatisfactory $(\mathbf{n}=\mathbf{1})$ & & \\
\hline Fair & 1 & 8.33 \\
\hline Poor & 0 & 0.0 \\
\hline Total & 12 & 100.0 \\
\hline
\end{tabular}




\section{DISCUSSION}

In most orthopedic centre in Bangladesh these injuries are managed by wound debridement and application of plaster cast or external fixator with subsequent referral to a department of plastic surgery for delayed soft tissue reconstruction. In cases fixation by external fixator apart from neurovascular injuries and permanent joint stiffness, pin tract infections have been the most serious limiting factor. $^{21}$ On the other hand delay of wound coverage by soft tissue and inadequate fixation by external fixator may lead to necrosis and bone death which enhances chronic osteomyelitis and nonunion. Subsequently these patients require very complex surgical procedures like Ilizarov external fixator, repeated refreshening of sclerosed surfaces and fixation by interlocking nail and bone graft. In the meantime patient developed contractures and stiffness of knee and ankle joints and also developed psychological problems. These make a burden for family, society and country. After four to five years some patients need amputation.

In this present study 12 patients were treated by immediate wound debridement, fixation of fracture by SIGN interlocking nail and wound coverage by muscle flap. All above procedures were done within 72 hours of injury.

Open fracture of tibia remains a major challenge to the Orthopaedic surgeons despite advancement of antibiotic therapy, microvascular surgery, and debridement of wounds and technique of stabilization. Major advance in the management came in 1973 with the introduction of microvascular free flaps. This reduced the time of union and the incidence of infection. Even with recent advancement some case ends up with amputation. ${ }^{5}$ Godina brought a new dimension to the treatment of these injuries by advocating the use of free tissue transfer very early, within five days of injury. ${ }^{8}$ Caudle and Stern reported effective internal fixation facilitates soft tissue cover and secondary bone grafting together with improved patient compliance but still early coverage and its advantages are debated. ${ }^{2,6-7,9,22,23}$ Coverage within 72 hours was emphasized by Wheelwright et al and Byrd et al. ${ }^{10,14}$ Both reports were compare able and encouraged this study to be carried out in our context where plastic surgeon are scarce and early coverage is not possible due lack of infrastructural support and often late referral. The operation was managed by a team consisting of one plastic surgeon, three orthopedic surgeons and one of them being trained in reconstructive surgery.

As a tertiary hospital lot of cases from near and far corners of the country either comes directly or referred to the National Institute of Traumatology and Orthopedic Rehabilitation (NITOR), Dhaka. All the patients were selected randomly on the basis of emergency attendance and 12 cases were included in this study. All selected cases were open fracture tibia-fibula Gustilo type III-B.
In this series, fracture tibia-fibula Gustilo type III B was treated by immediate wound debridement and internal fixation by intramedullary nail and wound coverage by muscles flap. All these procedures were done within seventy-two hours from the time of injury.

In this series, maximum age incidence was in 26 to 35 years age group (42\%). Range was 18 to 48 years with mean age of 34 years. This age incidence is similar with the study carried out by Fischer et al where mean age was 32 years with age ranging from 12 to 65 years. ${ }^{24}$ In the study of Caudle and Stern the age group ranged from 17 to 80 years with an average of 36 years. ${ }^{9}$ Similar pattern of incidence in these different studies point active and ambulant group exposed to the usual cause of fractures and as they are highly active earning group they required early return to their job.

Open tibial shaft fractures were found more in male than in female. In the present series $11(91.7 \%)$ cases were male and $1(8.3 \%)$ female. Male female ratio was 11:1. This may be due to the fact that females are less exposed to road traffic accidents in this country because of their frequency of traveling are considerably less than that of male. Motor vehicle accident was found to be the most common cause of injury in this series (11 cases). Among them 5 patients were bus passengers, 4 cases were pedestrian, 1 case truck accident, 2 cases were motorcycle accident.

In this series most fracture occurred in middle third of the shaft of the tibia fibula $(50 \%)$ followed by distal third $(40 \%)$. In the Shahidullah study most common site of fracture was in the middle third $(55 \%)$ followed by distal third $(40 \%)$ which is almost similar to the present study. ${ }^{18}$ In the study of Islam most common site of fracture was in the middle third $(45.15 \%)$ followed by distal third $(42 \%)$ which is almost similar to the present study. ${ }^{17}$

For the proper management of open fracture tibia fibula Gustilo III-B, the factors were very much important which were time and quality initial wound debridement, time of fracture fixation and skeletal stabilization and time of wound coverage by muscle flap. ${ }^{24-27}$

In this series, time of initial wound debridement was within 6 hours of injury in $6(50 \%)$ cases, within 7 to 12 hours injury in $4(33.3 \%)$ cases and 13 to 24 hours of injury in $2(16.67 \%)$ cases. Initial fixation of fracture was done within 25 to 48 hours in $5(41.67 \%)$ cases and 49 to 72 hours in $7(58.33 \%)$ cases. Wound coverage by muscle flap was done within 48 hours in 4 (33.33\%) cases and within 49 to 72 hours in $8(66.67 \%)$ cases. Minimum hospital stay was 14 days and maximum 26 days with a mean of 17.25 days observed in the present series. This result came out to be highly significant and much lower than other study Nazim and Fischer et al. ${ }^{21,24}$ In their study average hospital stay was 37.5 days and 36 days respectively. In this study lower hospital stay is due 
to early wound coverage and internal fixation within 72 hours of injury. However, $70 \%$ of open fractures are contaminated with bacteria at the time of injury. ${ }^{2}$ Early closure or soft tissue coverage can reduce nosocomial infection. Early soft tissue reconstruction in 3 to 7 days is recommended if the wound can be made clean and stable and is the key to reducing wound sepsis in type III open fractures. In this series bacteriological culture and sensitivity was performed in every cases. Out of 12 patients, 4 cases yielded no growth and 5 cases were infected with Staphylococcal infection that consistent with the results of the study of Gustilo and Anderson ${ }^{2}$. Rate of wound infection is associated with the adequacy of the debridement and the subsequent obliteration of the dead space by a healthy, well-vascularized and conforming muscle flap. ${ }^{14,15}$ It has been believed that the ability to debride the wound thoroughly depends on the surgeon's confidence that the resulting defect can be reliably filled with healthy tissue within a short period does need the presence of plastic surgeon Although the study was not a case-control or comparative one and timing of flap surgery and fracture fixation were not the parameter, nevertheless, in outcome measurement timing of surgery came out to be the single most important factor regarding better result. This is definitely better in the group where coverage was done between 5 to 10 days as recommended by Gustilo et al. ${ }^{28}$ Better results were evident from shorter period of hospital stay and absence of flap necrosis and bone infection. In this series fracture fixation and wound coverage by muscle flap were done within 72 hours of injury.

In this series all patients were managed by initial resuscitation, wound debridement, open reduction and internal fixation by SIGN interlocking nail, a solid nail inserted by an unreamed technique. ${ }^{29-34}$ Gopal et al advocated use of solid nail (AO-UTN) inserted by an unreamed manner. ${ }^{14} \mathrm{~A}$ solid nail obviates the potential dead space in a hollow nail and inserted without reaming to allow maximum preservation of the endosteal circulation which helps resist infection and aids in union of the fracture. ${ }^{30,31}$ In their study, the rate of infection in the nailed cases was only $3.0 \%$, and $74.0 \%$ united without a secondary procedure. Their results compared well with other reviews of open fractures management regarding choice of implant, emphasizing the effectiveness of this implant and fixation. ${ }^{14,15,18-20,30,32-34}$. Gopal et al emphasized on internal fixation and coverage early as they found low rate of complications with internal fixation (9\%). ${ }^{16}$ Most of these infections had significant predisposing factors, especially delay in flap cover. In this present series of the fractures united within 24 weeks and only one patient out of 12 developed superficial infections but no evidence of deep infection. Therefore despite the fact that open fracture is contaminated after good debridement stable internal fixation can reduce the risk of infection as after flap coverage the fracture is literally a closed one.
In this study $2(16.67 \%)$ of the cases were found to have restricted knee movements and no rotational and angulatory deformity. None of the patient developed neurovascular or compartment injury during this study. In this study satisfactory results were $91.67 \%$ and unsatisfactory were $8.33 \%$. Results of this study are superior to Islam who found $77 \%$ satisfactory results at NITOR, Dhaka and Shahidullah who found $75 \%$ satisfactory results. ${ }^{17,18}$ Behrens et al treated 28 cases of open tibial fracture between a period of 1978 to1980 and found $91 \%$ satisfactory results. ${ }^{35}$ Their results are similar to the present series probably due to early arrival of the patients to the emergency care, availability of equipment and expertise and available hospital facilities. ${ }^{36}$

This was a clinical study carried out at NITOR, Dhaka from July 2004 to June 2006 involving 12 patients with open fracture tibia and fibula Gustilo III B. All patients were managed by initial resuscitation, wound debridement, open reduction and internal fixation by SIGN interlocking nail and wound coverage by muscle flap. All procedures were done within 72 hours of injury. In this study out of 12 cases $9(75 \%)$ cases show excellent results, $2(16.67 \%)$ cases show good result. the results are consistent with the results of contemporary reports.

\section{CONCLUSION}

It has been concluded that early intramedullary fixation and exposed bone coverage by muscle flap is very important for prevention of infection, minimizing bone death simultaneously enhances bone healing and should be the method of choice if facilities and expertise permits.

Funding: No funding sources

Conflict of interest: None declared

Ethical approval: The study was approved by the institutional ethics committee

\section{REFERENCES}

1. Charnley J. The closed treatment of common fractures. 3rd edn. Livingstone, Edinburgh: 1961.

2. Gustilo RB, Anderson JT. Prevention of infection in the treatment of one thousand and twenty-five open fractures of long bones: retrospective and prospective analysis. J Bone Joint Surg [Am]. 1976;58:453-8.

3. Hansen ST Jr. Editorial. The type-IIIC tibial fracture: salvage or amputation. J Bone Joint Surg. 1987;69:799-800.

4. Georgiadis GM, Behrens FF, Joyce MJ, Earle S, Simmons AL. Open tibial fractures with severe softtissue loss: limb salvage com- pared with below-theknee amputation. J Bone Joint Surg. 1993;75:143141.

5. Fairhurst MJ. The Function of Below-Knee Amputee Versus the Patient With Salvaged Grade I11 Tibia1 Fracture. Clin Orthop Rel Res. 1994;301:227-32. 
6. Cierney G III, Byrd HS, Jones RE. Primary versus delayed soft tissue coverage for severe open tibial fractures: a comparison of results. Clin Orthop. 1983;178:54-63.

7. Russell GG, Henderson R, Arnett G. Primary or delayed closure for open tibial fractures. J Bone Joint Surg [Br]. 1990;7:125-8.

8. Godina M. Early microsurgical reconstruction of complex trauma of the extremities. Plast Reconstr Surg. 1986;78:285-92.

9. Caudle RJ, Stern PJ. Severe open fractures of the tibia. J Bone Joint Surg Am. 1987;69(6):801-7.

10. Wheelwright EF, Christie J, McQueen MM. External fixation for type III open tibial fractures. Bone Joint J. 1990;72(5):801-4.

11. Hertel R, Lambert SM, Muller S, Ballmer FT, Ganz $\mathrm{R}$. On the timing of soft-tissue reconstruction for open fractures of the lower leg. Arch Orthop Trauma Surg. 1999;119:7-12.

12. British Orthopaedic Association and British Association of Plastic Surgeons. A working party report. The early management of severe tibial fractures: the need for combined plastic and orthopaedic management. September, 1997.

13. Green AR. The courage to co-operate: the team approach to open fractures of the lower limb. Ann R Coll Surg Engl. 1994;76:365-6.

14. Byrd HB, Cierney G III, Tebbetts JB. The management of open tibial fractures with associated soft-tissue loss: external pin fixation with early flap coverage. Plast Reconstr Surg 1981;68:73-9

15. Gopal S, Majumder S, Batchelor AGB, Knight SL, Boer PD, Smith RM. 'Fix and flap: the radical Orthopaedic and plastic treatment of severe open fractures of the tibia'. J Bone Joint Surg. 2000;82:959-66.

16. Gopal S, Giannoudis PV, Murray A, Matthews SJ, Smith RM. The functional outcome of severe, open tibial fractures managed with early fixation and flap coverage. Bone \& Joint J. 2004;86(6):861-7.

17. Islam R. Result of management of open tibial shaft fractures with external skeletal fixation in adults, MS thesis, University of Dhaka. 1989.

18. Shahidullah M. Study on indigenous external fixator in the management of open fracture shaft of the tibia and fibula, MS thesis, University of Dhaka, 1996.

19. Tucker HL, Kendra JC, Kinnebrew TE. Management of unstable open and closed tibial fractures using the Ilizarov method. Clin Orthop Rel Res 1992;280:125-35.

20. Rahaman MH. Soft tissue Coverage by Gastrocnemius muscle flap in management of Gustilo type III B fracture of upper third of tibiafibula, MS thesis, University of Dhaka. 2003.

21. Nazim M. Soft tissue coverage by combined gastrocnemius and soleus muscle flap in management of Gustilo type III B fracture involving upper two-third of tibia-fibula, MS thesis, University of Dhaka. 2004.

22. Gustilo RB, Mendoza RM, Williams DN. Problems in the management of type III (severe) open fractures: a new classification of type III open fractures. J Trauma. 1984;24:742-6.

23. Hansen ST Jr. Open fractures in orthopaedic trauma protocols. Hansen and Swinotowski, editors. New York: Raven Press; 1993.

24. Fischer MD, Gustilo RB, Varecka TF. The timing of flap coverage, bone-grafting, and intramedullary nailing in patients who have a fracture of the tibial shaft with extensive soft-tissue injury. J Bone Joint Surg Am. 1991;73(9):1316-22.

25. Worlock P, Slack R, Harvey L, Mawhinney R. The prevention of infection in open fractures: an experimental study of the effect of fracture stability. Injury. 1994;25:31-8.

26. Holden CEA. The role of blood supply to soft tissue in the healing of diaphyseal fractures: an experimental study. J Bone Joint Surg. 1972;54:993-1000.

27. MacNab I, de Haas WG. The role of periosteal blood supply in the healing of fractures of the tibia. Clin Orthop. 1974;105:27-33.

28. Gustilo RB, Kyle RF, Templeman DC. Fracture of the tibia and fibula. Fractures and dislocations. Volume 2. St. Louis: Mosby- Year Book. Inc; 1993: 901-941.

29. Gustilo RB, Merkow RL, Templeman DA. The management of open fractures. J Bone Joint Surg Am. 1990;72(2):299-304.

30. Tornetta P III, Bergman M, Watnik N, Berkowitz G, Steuer J. Treatment of grade IIIB open tibial fractures: a prospective random- ised comparison of external fixation and non-reamed locked nailing. J Bone Joint Surg [Br]. 1994;76:13-9.

31. Rhinelander FW. Tibial blood supply in relation to fracture healing. Clin Orthop. 1974;105:34-81.

32. Keating JF, O'Brien PJ, Blachut PA, Meek RN, Broekhuyse HM. Interlocking intramedullary nailing of open fractures of the tibia. Clin Orthop. 1997;338:182-91.

33. Tu YK, Lin CH, Su JI, Hsu DT, Chen RJ. Unreamed interlocking nail versus external fixator for open type III tibia fractures. J Trauma Acute Care Surg. 1995;39(2):361-7.

34. Zirkle LG. SIGN, Technique Manual of I.M nail insertion, extraction and data reporting protocols, Surgical implant Generation Network. Washington: $1-30$.

35. Behrens F, Searls K. External fixation of the tibia. Basic concepts and prospective evaluation. Bone Joint J. 1986;68(2):246-54

36. Choudhury MA. Treatment of open tibial shaft fractures by Unreamed interlocking SIGN nail, MS thesis, University of Dhaka, 2000.

Cite this article as: Ali A, Rahman M, Faruquee SR, Islam T, Rahim ZZ, Yusuf A. Treatment of open fracture of shaft of tibia-fibula Gustilo type III-B by SIGN interlocking nail and wound coverage by muscle flap within 72 hours of injury. Int J Res Orthop 2017;3:898-903. 